\title{
Pola Komunikasi Pimpinan Terhadap Motivasi Kerja Karyawan
}

\author{
Bangkit Pratama $^{1}$, Veronika Setyadji ${ }^{2}$, Shulhuly Ashfahani ${ }^{3}$ \\ ${ }_{1,2,3}^{3}$ Sekolah Tinggi Ilmu Komunikasi Indonesia Maju \\ Email correspondent: rockerinlove017@gmail.com
}

\begin{abstract}
Abstrak
Kondisi dimana karyawan bekerja dengan kurang efektif dalam pencapaian targetnya, disebabkan belum terbentuknya pola komunikasi kepemimpinan yang mampu meningkatkan motivasi kerja karyawan. Tujuan penelitian ini untuk mengetahui Pola Komunikasi Pemimpin Divisi Legal Corporate PT. Perintis Pelayanan Paripurna Terhadap Motivasi Kerja Karyawan. Pemimpin di setiap kelompok diharapkan mampu menjalin kerjasama dengan bawahannya untuk mencapai tujuan perusahaan. Seperti yang terjadi pada divisi legal corporate PT. Perintis Pelayanan Paripurna, dimana komunikasi antara manajer dan karyawan disampaikan secara vertikal dan horizontal, sehingga membentuk suatu pola komunikasi. Adapun dalam penelitian ini menggunakan metode deskriptif kualitatif dengan studi kasus, yaitu pengumpulan data berdasarkan kenyataan di lapangan melalui observasi untuk meninjau dan mengamati objek penelitan, wawancara dengan responden untuk mengumpulkan data dan dokumentasi berupa foto-foto yang mendukung penelitian. Hasil penelitian menunjukkan bahwa komunikasi secara vertikal dan horizontal yang berjalan pada divisi legal corporate membentuk suatu pola komunikasi yaitu pola komunikasi all chanel (semua saluran), meskipun demikian masih terjadi kendala komunikasi dalam pekerjaan salah satunya adalah miss communications. Berdasarkan Informasi yang disampaikan manajer, dapat ditarik kesimpulan bahwa tipe kepemimpinan yang dimiliki manajer Divisi Legal Corporate termasuk pada kategori Lissez Faire, yaitu pemimpin menganggap bawahan sudah memahami tanggungjawabnya tanpa harus dijelaskan lagi., Salah satu cara untuk menjalin kerjasama tersebut yaitu dengan membangun pola komunikasi yang baik antara pimpinan dan bawahan dalam bentuk pertukaran informasi dan gagasan.
\end{abstract}

Kata Kunci: pola komunikasi, kepemimpinan, motivasi kerja, karyawan.

\begin{abstract}
Conditions where employees work less effectively in achieving their targets, due to the not yet formed leadership communication patterns that can increase employee motivation. The purpose of this study was to determine the Communication Pattern of PT. Perintis Pelayanan Paripurna for Employee Motivation. Leaders in each group are expected to be able to collaborate with subordinates to achieve company goals. As happened in the corporate legal division of PT. Perintis Pelayanan Paripurna, where communication between managers and employees is conveyed vertically and horizontally, thus forming a communication pattern. As for this research using descriptive qualitative methods with case studies, data collection based on reality in the field through observation to review and observe research objects, interviews with respondents to collect data, and documentation in the form of photographs that support research. The results showed that the vertical and horizontal communication that runs in the legal corporate division forms a communication pattern that is the communication pattern of all channels (all channels), however, communication obstacles still occur in the work, one of which is miss communications. Based on the information submitted by the manager, it can be concluded that the type of leadership owned by the Corporate Legal Division manager belongs to the Lissez. Faire category, where the leader assumes that subordinates already understand their responsibilities without having to be explained again. One way to establish cooperation is to establish communication patterns that are both between leaders and subordinates in the form of the exchange of information and ideas.
\end{abstract}

Keywords: communication patterns, leadership, work motivation, employees 


\section{Pendahuluan}

Setiap perusahaan selalu berupaya membentuk hubungan kerja yang harmonis antara pemimpin dan karyawan, untuk menjalankan upaya tersebut diperlukan seorang pimpinan yang mampu memberikan pengaruh yang besar dan dapat memotivasi para karyawannya dalam bekerja, untuk mencapai hasil yang optimal. Pemimpin yang efektif harus bisa memberikan arahan, evaluasi, dan koreksi terhadap usaha-usaha yang dilakukan oleh karyawan dalam mencapai tujuan perusahaan. ${ }^{1}$

Secara umum pola komunikasi yang dilakukan dalam sebuah perusahaan adalah komunikasi interpersonal, yaitu komunikasi yang bisa dilakukan individu dalam satu bagian, divisi/bagian dalam perusahaan, pimpinan, maupun antara pimpinan dan bawahan. ${ }^{1}$

Tercapainya tujuan perusahaan dapat terwujud apabila di dalamnya terjadi komunikasi yang baik antara pemimpin dan kayawannya ataupun sebaliknya. Informasi yang disampaikan oleh pimpinan apabila tidak diterima dengan baik oleh bawahan akan berdampak terjadinya kesalah pahaman/miss commnuications yang dapat menghambat pekerjaan sehingga target kerja tidak tercapai.

Keberhasilan seorang pemimpin dalam menyelesaikan masalah miss communications sebagian besar terletak pada keahliannya dalam berkomunikasi. Dengan kata lain suksesnya seorang pimpinan sangat bergantung kepada kemampuannya bekerja dengan orang-orang untuk meneruskan ide- ide, saran-saran dan membentuk suatu kelompok yang mendapatkan informasi dengan baik sehingga meminimalisir terjadinya masalah komunikasi. ${ }^{2}$

Sebagaimana yang diungkapkan Laswell, Komunikasi adalah pesan yang disampaikan kepada komunikan (penerima) dari komunikator (sumber) melalui saluran- saluran tertentu baik secara langsung/tidak langsung dengan maksud memberikan dampak/effect kepada komunikan sesuai dengan yang diingikan komunikator. Yang memenuhi 5 unsur who, says what, in which channel, to whom, with what effect. ${ }^{3}$

Pada proses pertukaran pesan pada suatu kelompok atau organisasi terdapat 2 arus/saluran komunikasi yaitu komuikasi vertikal dan horizontal. Komunikasi vertikal adalah arus komunikasi dua arah diantaranya adalah komunikasi yang dimulai dari pimpinan kepada bawahan atau biasa disebut dengan komunikasi kebawah (downward communication). sedangkan komunikasi ke atas (up ward communication) adalah komunikasi dari bawahan atau karyawan kepada pimpinan. ${ }^{3}$

Adapun Komunikasi horizontal adalah komunikasi secara mendatar dalam kelompok kerja yang sama, misalnya pimpinan dengan pimpinan, dan karyawan dengan karyawan. Tujuan dari komunikasi ini adalah saling menginformasi dan merencanakan suatu aktifitas, menyelesaikan konflik diantara anggota, menjamin pemahaman yang sama. ${ }^{4}$

Pemimpin juga harus mengetahui kelemahan dirinya sendiri dan bagaimana cara mengatasi kelemahannya. Memilih pola komunikasi yang tepat bisa secara efektif meningkatkan keahlian komunikasi diri sendiri.

Pola menurut Kamus Besar Bahasa Indonesia dapat di artikan sebagai bentuk (struktur) yang tetap. Krisyantoro menyatakan bahwa pola komunikasi dapat dipahami sebagai pola hubungan antara dua orang atau lebih dalam pengiriman dan penerimaan pesan dengan cara yang tepat sehingga pesan yang dimaksud dapat dipahami. ${ }^{5}$ Secara umum pola komunikasi merupakan cara bagaimana berkomunikasi baik verbal dan non verbal meliputi cara memberi dan menerima informasi dalam situasi tertentu. Berkaitan dengan penelitian ini pola komunikasi pemimpin merupakan cara berkomunikasi verbal dan non verbal yang dipakai pemimpin dalam mengarahkan, mempengaruhi dan memimpin bawahan agar tujuan atau pekerjaan dapat dijalan dengan baik. ${ }^{5}$

Komunikasi kepemimpinan terbagi menjadi menjadi 5 yaitu, pola roda yang bersifat penyampaian semua informasi hanya melalui 1 orang yaitu pemimpinnya, berbeda dengan pola rantai yang penyampaian informasinya secara berurutan seperti rantai, selanjutnya pola lingkaran, pola ini bersifat penyampaian yang berkelanjutan dari pemberi informasi membentuk melingkar kepada 
anggota lainnya dan pada akhirnya pemberi informasi akan mengevaluasi hasilnya dari orang terakhir yang menerima pesan, kemudian pola y, dimana anggota ketiga dapat mengirimkan dan menerima pesan dari dua orang lainnya, kemudian yang terakhir pola menyeluruh (all chanel) yang bersifat setiap anggota bisa berkomunikasi dengan setiap anggota lainnya. ${ }^{6}$

Menurut beberapa kelompok sarjana membagi Tipe Kepemimpinan berbagai macam, salah satunya Ada Kepemimpinan Laissez Faire Pada tipe kepemimpinan ini pemimpin tidak memimpin, dia membiarkan kelompoknya dan setiap orang berbuat semaunya sendiri. Pemimpin hanya berfungsi sebagai simbol, tidak bisa mengontrol anak buah, tidak mampu melaksanakan koordinasi kerja, tidak mampu menciptakan suasana kerja yang kooperatif. ${ }^{7}$

Pemahaman seorang pemimpin tentang pola komunikasi dapat meningkatkan motivasi kerja bawahan, Mulyanan berpendapat bahwa motivasi adalah kekuatan yang mendukung timbulnya semangat atau dorongan kerja. Lebih jauh dijelaskan, bahwa dalam kehidupan sehari- hari seseorang selalu mengadakan berbagai aktivitas. Salah satu aktivitas tersebut diwujudkan dalam gerakangerakan yang dinamakan kerja. ${ }^{7}$

Tanpa adanya motivasi dalam diri seseorang maka dapat dipastikan bahwa orang itu tidak akan bergerak sedikitpun dari tempatnya berada. Begitupun dalam dunia kerja, motivasi memegang peranan penting dalam usaha pencapaian tujuan suatu organisasi. ${ }^{8}$

Karyawan merupakan motor penggerak dari semua kegiatan yang berlangsung di perusahaan. Untuk mencapai kemajuan perusahaan harus dapat menentukan karyawan atau tenaga kerja yang sesuai dan Penentuan syarat-syarat dalam seleksi karyawan yang meliputi kualitas, kuantitas, tingkat pendidikan, pengalaman dan keahlian merupakan nilai yang sangat penting agar hasil yang dicapai sesuai dengan apa yang diinginkan lembaga tersebut. ${ }^{9}$

Divisi legal corporate merupakan salah satu unit kerja yang ada pada PT. Perintis Pelayanan Paripurna. Divisi legal corporate dipimpin oleh seorang manajer yang tugas utamanya mengelola dan menangani semua legalistas dokumen yang berkaitan dengan perizinan perusahaan yang meliputi Izin Usaha, Izin Bangunan, Izin Apotek, dan Izin Praktik Tenaga Kesehatan. Dalam menjalankan tugasnya, manajer dibantu oleh 3 orang staffnya yatu 1 orang admin dan 2 orang staff lapangan.

Proses komunikasi pada divisi legal corporate terbagi menjadi dua bentuk komunikasi yaitu vertikal dan horizontal. Komunikasi vertikal yang terjadi berupa pemberian perintah dan instruksi kerja dari manajer kepada karyawan, sedangkan komunikasi horizontal pada divisi tersebut terlihat adanya koordinasi antara sesama karyawan dalam penyelesaian tugas agar sesuai dengan target yang diberikan oleh manajer.

Seiring dengan berjalannya proses komunikasi pada Divisi legal corporate, ternyata masih terjadi hambatan komunikasi antara Manajer dan Staff, kurang jelasnya instruksi kerja yang diberikan Manajer ke pada Karyawan merupakan masalah pokok yang sering di alami oleh staff sehingga turunnya motivasi mereka dalam mencapai target kerja.

Kondisi tersebut dapat di hindari oleh manajer Divisi Legal Corporate apabila pola komunikasi kepemimpinannya dapat dikembangkan dengan memberikan kesempatan pada semua staff untuk menyampaikan kebutuhan informasi dari atasannya. Dengan menerapkan pola komunikasi kepemimpnan, diharapkan pemimpin dapat menganalisis karyawan dalam setiap situasi dengan menggunakan fasilitas yang ada demi mencapai suatu tujuan.

Hambatan komunikasi yang terjadi tentu sangat merugikan bagi divisi legal corporate karena bedampak pada menurunya motivasi karyawan sehingga target kerja tidak dapat dicapai yang tentunya perusahaan mendapatkan imbas kerugiannya jika tidak segera dicari solusinya. Hal tersebut memerlukan peran seorang manajer untuk segera mengambil keputusan yang tepat untuk memeberikan arahan dengan berkomunikasi.

Kondisi dimana karyawan bekerja dengan kurang efektif dan efisien dalam pencapaian targetnya, disebabkan belum terbentuknya pola komunikasi kepemimpinan yang mampu 
meningkatkan motivasi kerja karyawan. Hal tersebut perlu diupayakan agar komunikasi dalam divisi legal corporate selalu terjalin dengan baik. Dengan begitu akan memunculkan suatu keberhasilan yang ingin dicapai.

Tujuan penelitian ini ingin mengetahui Pola Komunikasi Pemimpin Divisi Legal Corporate PT. Perintis Pelayanan Paripurna Terhadap Motivasi Kerja Karyawan.

\section{Metode}

Metode yang dipakai dalam penelitian ini adalah metode kualitatif yaitu penelitian yang menghasilkan data deskriptif berupa kata- kata atau lisan dari orang-orang dan perilaku yang dapat diamati. Metode penelitian ini memusatkan diri secara intensif pada satu obyek tertentu dan mempelajarinya sebagai suatu kasus. ${ }^{10}$

Pemilihan responden yang akan digunakan pada penelitian ini menggunakan teknik Purposive Sampling dengan menentukan kriteria mengenai responden mana saja yang dapat dipilih sebagai sampel, dimana kriteria tersebut ditentukan dari divisi yang akan di teliti, jabatan responden, tugas dan wewenang responden dan berapa lama responden sudah bekerja. Hasil dari pengambilan sampling ini maka didapatkan sampling responden yaitu 1 manajer dan 3 karyawan divisi legal corporate PT. Perintis Pelayan Paripurna. ${ }^{11}$

Keabsahan data pada penelitian ini menggunakan metode triangulasi sumber data dengan memperhatikan tiga tipe sumber data yaitu waktu, misalnya kegiatan apa saja pada divisi legal corporate yang dilaksanakan harian, bulanan dan tahunan, yang kedua ruang, lokasi penelitan dilakukan di dua ruangan yang berbeda yaitu ruangan manajer dan ruangan staff divisi legal corporate, dan orang. Kemudian sumber yang ketiga yaitu orang, yaitu individu-individu sampel terpilih misalnya 1 orang manajer, 2 orang Legal Staff dan 1 orang Administratif Staff.

Data studi kasus yang diperoleh peneliti dikumpulkan dari berbagai sumber pada Divisi legal corporate dengan melakukan observasi dilokasi penelitian, wawancara para informan dan membuat dokumentasinya berupa foto dan rekaman hasil wawancara. ${ }^{11}$

Teknik pengamatan/ observasi pada penelitian ini adalah proses pengamatan dan ingatan di lingkungan PT Perintis Pelayanan Paripurna terhadap ruangan kerja manajer dan staff Divisi legal corporate, cara penyampaian perintah dari manajer, penyampaian laporan oleh staff, jadwal rapat dan aktifitas lain yang mendukung penelitian Observasi dalam penulisan ini menggunakan jenis observasi Partisipan yaitu mengambil peran dalam situasi yang berlangsung. Dengan demikian, akan mendapat pengalaman secara langsung dari aktivitas tersebut sehingga informasi yang diperoleh menjadi lebih mendalam.

Setelah proses observasi, penulis masuk pada tahap wawancara. Tahap ini dilakukan secara bergantian disesuaikan dengan jadwal manajer dan staff Divisi legal corporate. Wawancara atau interview dalam penulisan ini menggunakan wawancara terbuka bagi pimpinan dan karyawan mengenai pola komunikasi kepemimpinan, motivasi serta target kerja, yaitu mengajukan pertanyaan yang dirancang untuk mendukung kelengkapan data penbelitian.

Wawancara diperlukan untuk mendapatkan informasi melalui tanya jawab, sehingga dapat dibangun pengertian dalam pengumpulan data penelitian. Pada penelitian ini wawancara bertujuan untuk mendapatkan informasi mengeneai pola komunikasi pimpinan dan motivasi bawahan.

Sebagai pelengkap data yang didapat dari tahapan observasi dan wawancara, maka dibutuhkan dokumentasi. Dokumentasi itu terdiri dari gambar/foto dan rekaman. Lincoln dan Guba mengartikan rekaman sebagai setiap tulisan atau pernyataan yang dipersiapkan oleh atau untuk individual atau organisasi dengan tujuan membuktikan adanya suatu peristiwa. ${ }^{11}$

Fokus studi kasus terletak pada bagaimana staff Divisi legal corporate berpikir, melakukan sesuatu, atau bahkan meng- embangkan diri. Fokus ini dinilai penting karena dibutuhkan analisis yang intensif, bukan berfokus pada status, kemajuan, tindakan, atau pikiran yang dimilikinya. Studi kasus 
adalah metode penelitian yang bertujuan untuk menyajikan laporan kepada pembaca mengenai bagaimana rasanya terlibat dalam suatu kejadian dan menjadi bagian di dalamnya dengan hasil yang dituangkan sebagai bentuk gambaran dari realita dan fenomena yang ada.

Studi kasus pada penelitian ini fokus pada pola komunikasi pemimpin dalam menghadapi masalah komunikasi antara pimpinan dan bawahan yang menjadi hambatan dalam mencapai target kerja, diterapkannya studi kasus ini untuk memahami pola komunikasi lebih mendalam dengan dipraktekkan secara integratif dan komprehensif pada manajer dan karyawan Divisi legal corporate. Hal ini dilakukan untuk mendalami masalah mengenai pola komunikasi yang diteliti, serta masalah yang dihadapi supaya dapat terselesaikan. ${ }^{12}$

Teknik pengumpulan data yang digunakan pada penelitian ini adalah sumber primer dan sumber sekunder. Sumber data primer didapat secara langsung dari hasil wawancara dengan manajer dan para staffnya, untuk data sekunder diperoleh dari sumber yang pernah ada seperti buku, penelitian terdahulu, jurnal serta profil dan visi misi perusahaan. Menurut Sugiyono teknik pengumpulan data merupakan langkah yang paling strategis dalam penelitian, karena tujuan utama dari penelitian adalah mendapatkan data. ${ }^{13}$

Setelah memperoleh semua data yang berkaitan dengan pola komunikasi kepemimpinan dan motivasi kerja karyawan, selanjutnya peneliti menganalisis data tersebut. Analisis tersebut merupakan upaya yang berlanjut, berulang dan penarikan kesimpulan menjadi gambaran tentang pola komunikasi pemimpin pada divisi legal corporate terhadap meningkatnya motivasi karyawan.

Proses analisis data kualitatif penelitan ini dimulai dengan mencatat hasil pengamatan dilapangan dan diberikan kode/tanda agar sumber datanya tetap dapat ditelusuri. Selanjutnya mengumpulkan, memilah-milah, mengklasifikasi, membuat ihktisar dan membuat indeksnya, kemudian membuat agar kategori data itu mempunyai makna, mencari dan menentukan pola dan hubungan-hubungan serta membuat temuan -temuan umum yang ada pada divisi tersebut. Proses ini berlangsung terus-menerus selama penelitian berlangsung, bahkan sebelum data benar-benar terkumpul. ${ }^{14}$

Analisis data pada penelitian ini menggunakan 3 teknis analisis data dari Miles dan Huberman yaitu Reduksi data, penyajian data dan penarikan kesimpulan. ${ }^{11}$

Reduksi Data pada penelitian ini menggunakan hasil wawancara dengan manajer, staff legal perjanjian, staff legal perizinan dan staff admin terkait pemberian tugas dari pimpinan, penyampaian informasi, serta penyampaian laporan hasil kerja dari staff kepada manajer. Data yang didapat diolah dengan melihat dari teori untuk mendapatkan kejelasan pada pola komunikasi kepempinan divisi legal corporate terhadap motivasi karyawan.

Baik data yang terdapat di lapangan maupun yang terdapat pada kepustakaan. Data dikumpulkan, dipilih secara selektif dengan disesuaikan pada permasalahan yang diangkat dalam penulisan. Kemudian dilakukan pengolahan dengan meneliti ulang data yang didapat, apakah data tersebut sudah cukup baik dan dapat segera dipersiapkan untuk proses selanjutnya

Dalam penyajian data pada penelitian ini dilakukan secara induktif, yakni menguraikan setiap permasalahan dengan cara pemaparan secara umum kemudian menjelaskan dalam pembahasan yang lebih spesifik, contohnya informasi dari manajer dan bawahan mengenai instruksi kerja yang menjadi kendala maka informasi tersebut di uraikan terlebih dahulu, kemudian diamati untuk membandingkan dan terakhir dibahas untuk dijelaskan titik masalahnya agar terbentuk suatu solusi. Selanjutnya penliti melakukan Penyajian data berupa teks hasil wawancara supaya lebih mudah dipahami.

Langkah selanjutnya dalam menganalisis data kualitatif adalah penarikan kesimpulan dan verifikasi, setiap kesimpulan awal yang dikemukakan masih bersifat sementara dan akan berubah bila ditemukan bukti-bukti kuat yang mendukung pada tahap pengumpulan data berikutnya. Upaya penarikan kesimpulan yang dilakukan secara terus- menerus selama berada di lapangan. Kesimpulan itu kemudian diverifikasi selama penulisan berlangsung dengan cara meninjau kembali catatan lapangan sehingga terbentuk penegasan kesimpulan. ${ }^{12}$ Melalui data yang disajikan tersebut memberi 
kemungkinan pada peneliti untuk penarikan kesimpulan dan pengambilan tindakan terhadap kendala komunikasi yang ada pada Divisi legal corporate.

\section{Hasil dan Pembahasan}

Divisi legal corporate merupakan salah satu unit kerja dari PT. Perintis Pelayanan Paripurna yang dipimpin oleh seorang manager dan bertugas mengelola sekaligus memastikan dan menangani semua legalistas dokumen yang berkaitan dengan perizinan perusahaan yang meliputi Izin Usaha, Izin Bangunan, Izin Apotek, dan Izin Praktik Tenaga Kesehatan.

Susunan organisasi pada Divisi Legal Corporate terdiri dari satu orang pemimpin/manajer, kemudian 2 orang Legal Staff dan 1 orang Administratif Staff. Seluruh anggota pada divisi tersebut mempunyai tugas-tugas pokok dan tugas-tugas umum yang sudah ditentukan oleh peraturan perusahaan.

Berdasarkan Hasil penelitian yang dilakukan pada divisi legal corporate PT.Perintis Pelayanan Paripurna, diperoleh suatu gambaran bahwa proses komunikasi pada divisi legal corporate terbagi menjadi dua bentuk komunikasi yaitu vertikal dan horizontal. Komunikasi vertikal yang terjadi berupa pemberian perintah dan instruksi kerja dari manajer kepada karyawan dan laporan hasil pekerjaan yang telah diselesaikan karyawan maupun kendala yang terjadi dilapangan, sedangkan komunikasi horizontal pada divisi tersebut terlihat adanya koordinasi antara sesama karyawan dalam penyelesaian tugas agar sesuai dengan target yang diberikan oleh manajer.

Seiring dengan berjalannya proses komunikasi pada Divisi legal corporate, ternyata masih terjadi hambatan komunikasi antara Manajer dan Staff, kurang jelasnya instruksi kerja yang diberikan Manajer ke pada Karyawan dan tidak adanya kesempatan untuk staff bertanya, merupakan masalah pokok yang sering di alami oleh staff sehingga turunnya motivasi mereka dalam mencapai target kerja.

Kondisi tersebut dapat di hindari oleh manajer Divisi Legal Corporate apabila pola komunikasi kepemimpinannya dapat dikembangkan dengan memberikan kesempatan pada semua staff untuk menyampaikan kebutuhan informasi dari atasannya. Dengan menerapkan pola komunikasi kepemimpnan, diharapkan pemimpin dapat menganalisis karyawan dalam setiap situasi dengan menggunakan fasilitas yang ada demi mencapai suatu tujuan. ${ }^{15}$

Perintah dari manajer berupa tugas untuk mengurus izin apotek dan membuat perjanjian kerja sama dengan pengelola gedung/ruko, perintah yang disampaikan merupakan tugas pokok dari seorang staff. Selain memberikan perintah, manajer juga meminta informasi mengenai perkembangan pekerjaan yang dilakukan dalam bentuk laporan dari staff.

Dari proses komunikasi tersebut menggambarkan pola komunikasi yang membentuk pola komunikasi semua saluran (all chanel) dimana semua orang yang ada dalam divisi legal corporate dapat menyampaikan informasi secara langsung tanpa harus melewati perantara. Meskipun pola all chanel sudah berjalan pada divisi legal corporate namun tidak dapat dihindari adanya miss communications ataupun kesalahpahaman yang terjadi antara manajer dan staff.

Manajer selaku pimpinan, memiliki wewenang dan kuasa untuk memerintah bawahan dan mengambil keputusan mengenai dokumen yang perlu digunakan seperti IMB, SIUP dan Akta Perusahaan untuk menunjang pekerjaan divisi legal corporate. Setiap perintah dan keputusan manajer harus diterima serta dilaksanakan oleh staff tanpa memberikan kesempatan kepada staff untuk membantah/menolak perintah tersebut.

Perintah maupun himbauan dari manajer akan disampaikan dalam rapat internal divisi legal corporate seminggu sekali yang dihadiri oleh seluruh anggota termasuk legal officer dan administratif staff guna memastikan perkembangan tugas yang diberikan tidak mengalami hambatan dan dapat diselesaikan secepatnya.

Diadakan rapat internal tersebut membantu manajer dalam memantau perkembangan pekerjaan yang sedang berjalan dan memastikan tidak ada kendala sehingga berjalan dengan baik serta mampu 
diselesaikan. Agenda rapat internal tersebut juga membahas perencanaan tugas yang harus diselesaikan, antara lain kapan dimulainya tugas tersebut, dokumen apa saja yang diperlukan, memerlukan persetujuan divisi mana saja, dan berapa biaya yang dibutuhkan.

Pembagian wilayah kerja officer juga masuk kedalam agenda rapat internal divisi legal corporate. Perintah yang diberikan manajer selalu dituntut untuk segera diselesaikan tanpa ada kejelasan jangka waktu pekerjaan yang harus diselesaikan. Hal tersebut membuat officer merasa bekerja dibawah tekanan. Perintah yang diberikan manajer tidak membuat bawahan termotivasi untuk segera menyelesaikan, contohnya saat manajer menugaskan bagian admin untuk menyiapkan rekap pengeluaran biaya perizinan, manajer sering memberikan perintahnya disaat jam istirahat bahkan pernah di hari libur sehingga admin tidak merasa termotivasi untuk secepatnya mengerjakan perintah tersebut

Selain tidak dapat ditolak/dibantah, perintah yang disampaikan oleh manajer selalu bersamaan dengan tugas lain, tidak ada arahan, selalu terburu-buru dalam mengambil keputusan, menganggap semua perintah itu urgent dan harus segera dilakukan. Istilah urgent digunakan manajer dalam setiap perintah yang diberikan, baik itu penting untuk segera diselesaikan maupun yang tidak penting. Update data apotek dinilai tidak penting karena bisa dilakukan kapan saja dan tidak memerlukan waktu yang banyak dalam menyelesaikanya, jadi tidak masuk dalam kategori urgent.

Gaya kepemimpinan yang dimiliki manajer menjadi faktor yang membuat pola komunikasi all chanel pada divisi legal corporate belum berjalan efektif dan masih terdapat miss communications, karena kepemimpinan manajer saat ini serupa dengan tipe Laissez Faire yaitu perintah yang disampaikan kepada karyawan hanya intinya saja (tidak lengkap) karena manajer menganggap karyawan mengetahui apa yang menjadi tujuan, sasaran yang dicapai, dan tugas yang harus dilaksanakan oleh masing- masing anggota. Manajer juga tidak memberikan jangka waktu penyelesaian dari kendala tersebut yang terjadi malah manajer semakin sering menghubungi staff guna menanyakan kapan kendala itu selesai, hampir setiap hari bahkan hari libur manajer tetap memantau laporan dari kendala tersebut.

Perintah maupun himbauan dari manajer akan disampaikan dalam rapat internal divisi legal corporate seminggu sekali yang dihadiri oleh seluruh anggota termasuk legal staff dan administratif staff guna memastikan perkembangan tugas yang diberikan tidak mengalami hambatan dan dapat diselesaikan secepatnya. Perintah tersebut selalu dituntut untuk segera diselesaikan tanpa ada kejelasan jangka waktu pekerjaan yang harus diselesaikan. Hal tersebut membuat staff merasa bekerja dibawah tekanan. Perintah yang diberikan manajer tidak membuat bawahan termotivasi untuk segera menyelesaikan, contohnya saat manajer menugaskan bagian admin untuk menyiapkan rekap pengeluaran biaya perizinan, manajer sering memberikan perintahnya disaat jam istirahat bahkan pernah di hari libur sehingga admin tidak merasa termotivasi untuk secepatnya mengerjakan perintah tersebut.

Sikap manajer yang tidak memberikan solusi, dan cenderung mendesak, membuat staff bekerja dengan persaaan dibawah tekanan. Hal tersebut tidak baik jika terus menerus berjalan tanpa adanya perbaikan. Salah satu perbaikan yang dapat dilakukan oleh manajer yaitu dengan rutin mengadaka rapat internal untuk lebih mendengarkan pendapat, saran maupun keluhan dari bawahan.

Diadakan rapat internal tersebut membantu manajer dalam memantau perkembangan pekerjaan yang sedang berjalan dan memastikan tidak ada kendala sehingga berjalan dengan baik serta mampu diselesaikan. Agenda rapat internal tersebut juga membahas perencanaan tugas yang harus diselesaikan, antara lain kapan dimulainya tugas tersebut, dokumen apa saja yang diperlukan, memerlukan persetujuan divisi mana saja, dan berapa biaya yang dibutuhkan.

Pembagian wilayah kerja staff juga masuk kedalam agenda rapat internal divisi legal corporate. Perintah yang diberikan manajer selalu dituntut untuk segera diselesaikan tanpa ada kejelasan jangka waktu pekerjaan yang harus diselesaikan. Hal tersebut membuat staff merasa bekerja dibawah tekanan. 
Dalam hal memotivasi, komunikasi yang dilakukan manajer divisi legal corporate dalam memberikan perintah - perintah dirasa belum jelas dan selalu terburu-buru dalam mengambil keputusan, tidak memberikan solusi terhadap kendala menyebabkan bawahan tidak termotivasi untuk mengerjakan dengan segera, sehingga kedisiplinan dan rasa tanggungjawab karyawan terhadap tugastugasnya tidak didapat hasil yang maksimal.

Motivasi yang bisa diberikan oleh manajer bukanlah kata-kata bijak seperti yang diberikan motivator di televisi, melainkan dalam bentuk yang bisa dirasakan langsung oleh karyawan, seperti insentif bila target tercapai, bonus tambahan, perhatian secara personal, arahan/bimbingan, memberikan penghargaan dan juga promosi jabatan dapat meningkatkan motivasi karyawan dalam mencapai target kerja. Target kerja yang mampu dicapai oleh karyawan, secara tidak langsung adalah cerminan keberhasilan manajer dalam mengelola suatu divisi yang tentunya keberhasilan tersebut menjadi nilai tambah bagi manajer berdasarkan penilaian direktur.

Tercapainya target kerja sangat didukung oleh motivasi yang diberikan manajer kepada karyawan, dengan asumsi semakin tinggi motivasi kerja karyawan maka diharapkan target kerja perusahaan akan semakin baik, dapat dibuktikan dengan memberikan motivasi secara langsung misalnya memberikan apresiasi dengan memberikan pengharaan terhadap hasil pencapaian target karyawan dalam bentuk promosi jabatan, ataupun apresiasi berupa wisata bersama-sama seluruh anggota divisi untuk merayakan keberhasilan dalam pencapaian target dengan diberikan apresiasi maka staff Legal akan termotivasi untuk menyelesaikan target target kerjanya.

\section{Kesimpulan}

Berdasarkan hasil penelitian yang telah dikemukakan pada pembahasan sebelumnya disimpulkan bahwa pertukaran pesan/informasi antara manajer dan karyawan dalam divisi legal corporate PT. Perintis Pelayanan Paripurna disampaikan secara vertikal yaitu komunikasi yang berasal dari atas kebawah maupun dari bawah keatas. Selain itu terdapat juga komunikasi secara horizontal, terlihat pada interaksi yang terjalin pada level jabatan sesama manajer maupun pada kalangan sesama staff pada divisi legal corporate yang terjalin dengan baik karena kekompakan yang dibangun antar sesama staff.

Dari proses komunikasi tersebut menggambarkan pola komunikasi yang membentuk pola komunikasi semua saluran (all chanel) dimana semua orang yang ada dalam divisi legal corporate dapat menyampaikan informasi secara langsung tanpa harus melewati perantara. Meskipun pola all chanel sudah berjalan pada divisi legal corporate namun tidak dapat dihindari adanya miss communications.

Gaya kepemimpinan yang dimiliki manajer melatar belakangi pola komunikasi all chanel pada divisi legal corporate belum berjalan efektif dan masih terdapat miss communications, karena kepemimpinan manajer saat ini serupa dengan tipe Laissez Faire yaitu perintah yang disampaikan kepada staff hanya intinya saja (tidak lengkap) karena manajer menganggap staff mengetahui apa yang menjadi tujuan, sasaran yang dicapai, dan tugas yang harus dilaksanakan oleh masing- masing anggota.

Motivasi staff dalam mengerjakan dan menyelesaikan tugas belum dapat ditingkatkan apabila pola komunikasi yang baik tidak didukung juga dengan tipe kepemimpinan yang baik. Motivasi yang bisa dirasakan langsung oleh staff, seperti insentif bila target tercapai, bonus tambahan, perhatian secara personal, arahan/bimbingan, memberikan penghargaan dan juga promosi jabatan dapat meningkatkan motivasi staff dalam mencapai target kerja.

Target kerja dapat dicapai oleh staff divisi legal corporate jika manajer selaku pemimpin mampu menjalin komunikasi yang baik dengan bawahan serta mampu meningkatkan motivasi dengan cara memberikan apresiasi kepada hasil kerja bawahan dan mampu memberikan solusi terhadap kendala yang dihadapi oleh bawahan. 


\section{JIKOM}

Jurnal Ilmiah Komunikasi

Volume 12, No.02, Juli. 2020

\section{References}

1. Mulyana D, editor. Komunikasi Organisasi, Strategi Meningkatkan Kinerja Perusahaan. Bandung: PT. Remaja Rosdakarya; 2005.

2. Cangara H. Pengantar Ilmu Komunikasi. PT. RajaGrafindo Persada; 2000.

3. Setyadji V, Wahyuni PH. Pengemasan Budaya Lokal Dalam Program Televisi Lokal (Studi Kasus Program Budaya Â Adiluhungâ Pada Stasiun Televisi Lokal Yogyakarta Â Jogya Tvâ) (Doctoral Dissertation, [Yogyakarta]. Universitas Gajah Mada; 2013.

4. Winardi J. Teori Organisasi \& Pengorganisasian. Teor Organ Pengorganisasian. 2006;16:1-20.

5. Krisyantoro R. Teknik Praktik Riset Komunikasi. Jakarta: Kencana Prenada Media Group; 2008.

6. Afrianty R. Pola Komunikasi Kepemimpinan Dalam Meningkatkan Kinerja Pegawai Di Badan Pemberdayaan Masyarakat Dan Pemerintahan Desa Kabupaten Pelalawan. J Jom Fisip. 2015;2(1).

7. Faturahman BM. Kepemimpinan dalam Budaya Organisasi. Madani. 2018;10(1):1- 11.

8. Mahmudah D. Komunikasi, Gaya Kepemimpinan, dan Motivasi dalam Organisasi (Communication, Leadership Style and Motivation in organization). J Stud Komun dan Media. 2015;19(2):285-302.

9. Abdullah MM. Manajemen dan Evaluasi Kinerja Karyawan. Perpustakaan Nasional RI. 2014. 1-228 p.

10. Anggito A, Setiawan J. Metodologi penelitian kualitatif. CV Jejak (Jejak Publisher); 2018.

11. Gunawan I. KUALITATIF Imam Gunawan. Pendidikan [Internet]. 2016;27. Available from: http://fip.um.ac.id/wp- content/uploads/2015/12/3_Metpen- Kualitatif.pdf

12. Fitrah M. Metodologi penelitian: penelitian kualitatif, tindakan kelas \& studi kasus. CV Jejak (Jejak Publisher); 2018.

13. SUGIYONO P. Memahami penelitian kualitatif. Bandung: Alfabeta; 2005.

14. SUGIARTO E. Menyusun Proposal Penelitian Kualitatif: Skripsi dan Tesis. Suaka Media. Diandra Kreatif; 2017.

15. Sasongko AF. Aktivitas Penggunaan Portal TELKOM sebagai Media Komunikasi Internal terhadap Pemenuhan Kebutuhan Informasi Karyawan PT. TELKOM DCS REGIONAL SEMARANG. J Messenger. 2017;9(2):203. 